\title{
ANALISIS KESALAHAN SISWA DALAM MENYELESAIKAN SOAL CERITA SISTEM PERSAMAAN LINEAR DUA VARIABEL MENGGUNAKAN FASE NEWMAN
}

\author{
Sonya Grace Eveline Sianipar \\ Jurusan Matematika, FMIPA, Universitas Negeri Surabaya \\ sonyasianipar@mhs.unesa.ac.id
}

\begin{abstract}
Abstrak
Dalam proses pembelajaran matematika, siswa seringkali melakukan kesalahan dalam mengerjakan soal, terutama soal cerita. Dalam mengerjakan soal cerita siswa diharuskan mengerti isi soal cerita dan memisalkan dalam bentuk symbol matematika dan memprosesnya menggunakan metode matematika hingga tahap akhir dan menarik kesimpulan. Tujuan penelitian ini adalah untuk mendiskripsikan letak, jenis, dan penyebab kesalahan siswa kelas VIII dalam menyelesaikan soal cerita topik Sistem Persamaan Linear Dua Variabel (SPLDV) menggunakan analisis kesalahan Newmann yaitu kesalahan membaca, kesalahan memahami, kesalahan transformasi, kesalahan kemampuan proses dan kesalahan mengembalikan hasil akhir model ke masalah awal.

Hasil penelitian menunjukkan, kedua siswa tersebut banyak melakukan kesalahan pada tahap membaca soal cerita, tahap transformasi ke bentuk kalimat matematika hingga tahap mengembalikan jawaban ke masalah awal soal. Jenis kesalahan yang dilakukan: siswa salah konsep dalam memodelkan dan salah dalam melakukan operasi hitung. Adapun penyebab kesalahannya adalah subjek lemah dalam konsep variabel, tidak mampu membaca simbol-simbol yang tersirat dalam soal, tidak mampu menerjemahkan kalimat soal ke dalam bentuk model matematika dengan tepat, kurang mempu membuat persamaan ekuivalen, kurang mampu menentukan hasil perhitungan dengan tepat.
\end{abstract}

Kata Kunci: Analisis Kesalahan, Newmann, SPLDV, dan Soal Cerita

\section{Abstract}

In learning mathematics, students often make mistakes in solving math questions, especially story questions. Solving story questions, students are required to understand the contents of the story questions and take them in the form of mathematical symbols and process them using mathematical methods until the final stage and draw conclusions. The aim of the research is to describe locations, types, and causes of VIII grade Students' errors in solving story questions of Two-variable Linear Equality System using Newmann's Error Analysis. Newman's Error Analysis namely Reading error, comprehension error, transformation error, process skill error, and an encoding error.

The result of this research says the students made many mistakes in reading the story question, transforming into a mathematic model onto the encoding stage. The types of errors that were made were: students were wrong concepts, there including wrong in modeling and students were wrong in operations, i.e. students did not use the right arithmetic operation. The cause of the errors is that the subject is bad in the concept of the variable, including being unable to read the symbols implied in the problem. Unable to transform question to math-model correctly, weak in making equivalent questions, and weak in determining calculation result rightly.

Keywords: Error Analysis, Newmann, Two-variables Linear Equality System, and Story Question.

\section{PENDAHULUAN}

Dalam proses pembelajaran matematika, seringkali siswa mengalami kesalahan dalam mengerjakan soal-soal matematika, khususnya yang berbentuk soal cerita. Dalam menyelesaikan soal cerita, siswa diharuskan mengerti betul isi soal cerita tersebut kemudian memisalkan objek-objek yang harus diselesaikan menggunakan simbol matematika, kemudian memprosesnya menggunakan metode matematika hingga tahap akhir penyelesaian dan menarik kesimpulan. Pada umumnya, siswa mengalami kesalahan dalam memahami soal, kesalahan transformasi, kesalahan keterampilan proses, dan kesalahan penulisan jawaban akhir (Sunardiningsih, dkk, 2019)

Sistem Persamaan Linear Dua Variabel (SPLDV) merupakan salah satu materi aljabar yang diajarkan di kelas VIII SMP. Menurut Capate dan Lapinid (dalam Anna, dkk 2018:67), dengan melakukan Uji Penilaian Matematika pada siswa kelas VIII di Philiphina SPLDV termasuk materi yang sulit, presentase nilai penyelesaian materi SPL dalam grafik, aljabar, dan terkait pemecahan masalah materi SPL di bawah angka $50 \%$.

Begitu juga yang terjadi ketika pelajaran di kelas, sering ditemukan beberapa siswa mengalami kesulitan mempelajari materi SPLDV terutama dalam bentuk soal 
cerita. Siswa merasa sulit mengerti permasalahan yang ada dalam soal cerita dan menafsirkannya kedalam model matematika. Peneliti melakukan interview dengan seorang siswa kelas VIII di SMPN 1 Tembilahan Hulu, Kabupaten Indragiri Hilir, Riau untuk memperkuat data, siswa tersebut mengatakan masih kesulitan dalam menyelesaikan soal SPLDV yang berbentuk soal cerita, dan sesuai dengan hasil tes harian siswa tersebut yang masih berada di bawah kriteria ketuntasan minimal.

Karnasih (2015:37) mengatakan, "salah satu permasalahan dalam menyelesaiakan soal-soal matematika adalah soal matematika yang menggunakan kata-kata atau soal cerita". Hasil penelitian Rahayu (2017:338) menyebutkan mayoritas siswa kelas VIII B SMPN 1 Salam, kabupaten Magelang masih salah dalam mengerjakan soal cerita materi SPLDV.

Data tersebut menunjukkan masih banyak siswa yang keliru dalam mengerjakan soal cerita SPLDV, sehingga analisis kesalahan siswa dalam menyelesaikan soal-soal cerita SPLDV perlu dilakukan.

Metode analsis Newman seringkali digunakan untuk menganalisis siswa yang kesulitan memahami soal cerita matematika. Dalam analisis Newman sendiri terdapat 5 fase dalam memahami dan menganalisis bagaimana siswa memecahkan bentuk soal uraian. (1) membaca (reading), (2) memahami (comprehension), (3) transformasi (transformation), (4) keterampilan proses (process skill), (5) mengembalikan jawaban model ke masalah awal. (encoding). Dari beberapa metode analisis kesalahan, metode Newman dianggap lebih lengkap dikarenakan terdapat fase membaca.

Selain itu, metode analisis Newman juga memaparkan jenis-jenis dan letak dari kesalahan siswa dalam mengerjakan soal cerita. Dengan diketahuinya letak dan jenis kesalahannya maka akan diketahui pula faktor yang berpengaruh pada kesalahan siswa tersebut.

Hasil penelitian Susanti (2017) yang menganalisis kesalahan siswa dalam mengerjakan soal cerita materi program linear berdasarkan fase Newman menunjukkan pada fase membaca siswa dapat membaca dengan lancar, namun ternyata siswa tidak mengerti sepenuhnya kalimat yang dibaca. Fase memahami, siswa tidak menyatakan yang diketahui dan ditanyakan dalam soal, fase transformasi, siswa keliru mengubah informasi dalam soal ke bentuk model matematika, dan tidak memahami rumus yang digunakan, ketrampilan proses, siswa keliru dalam melakukan komputasi matematika dan fase penulisan hasil akhir, siswa tidak menyatakan jawaban akhir yang sesuai dengan yang ditanyakan soal. Berdasarkan hasil tersebut diketahui siswa mengalami kesalahan pada fase memodelkan soal, memproses, hingga menyimpulkan jawaban.

Berdasarkan uraian di atas, perlu dilakukan suatu upaya untuk mengetahui jenis-jenis kesalahan, letak-letak kesalahan dan faktor-faktor penyebab kesalahan siswa dalam menyelesaiakan soal cerita Sistem Persamaan Linear Dua Variable (SPLDV) agar dapat dijadikan pertimbangan dalam merancang soal cerita sistem persamaan linear dua variable untuk meningkatkan hasil belajar siswa.

\section{AnALISIS KeSAlahan}

Analisis merupakan penyelidikan atau penguraian suatu permasalahan untuk diketahui apa sebab dan bagaimana permasalahan tersebut terjadi dengan memecah topik yang lebih kompleks menjadi bagian yang lebih kecil dan ditelaah hubungan antar bagian untuk memperoleh kesatuan pemahaman yang tepat dan menyeluruh. Sejalan dengan pengertian tersebut, analisis kesalahan menurut kamus bahasa indonesia, Kamarullah (dalam Azis 2013:7) analisis adalah suatu upaya menemukan, mengklasifikasi, dan menginterprestasikan fenomena yang menjadi sasaran penelitian. Kesalahan dapat diartikan sebagai suatu proses atau bentuk yang salah dari sesuatu yang sudah ditetapkan; suatu proses atau bentuk yang salah dari patokan yang dianggap benar; suatu proses atau bentuk yang salah dari prosedur yang telah disepakati. Kesalahan yang dilakukan siswa dapat menjadi bahan pertimbangan bagi guru untuk mengetahui dimana letak kelemahan siswa dalam memahami suatu materi yang sedang dipelajarinya.

Berdasarkan uraian tersebut dapat dikatakan bahwa analisis kesalahan merupakan suatu pemeriksaan terhadap proses atau bentuk yang dianggap salah untuk mengetahui akar permasalahan tersebut terjadi. Dalam penelitian ini, analisis kesalahan dilakukan dengan menggambarkankan kesalahan siswa serts faktor penyebab siswa keliru mengerjakan soal cerita sistem persamaan linear dua variabel menggunakan metode Newman.

\section{Soal Cerita Matematika}

Soal cerita matematika merupakan soal yang mengilustrasikan permasalahan kehidupan sehari-hari yang penyelesaiannya menggunakan model matematika.

Soal cerita seringkali digunakan untuk mengenali kemampuan siswa dalam bidang studi matematika. Soal cerita merupakan tingkat lanjut dari soal hitungan yang dikaitkan dengan permasalahan nyata di lingkungan sekitar. Penerapan konsep yang sedang dipelajari dapat disajikan dalam bentuk soal cerita. Selain untuk melihat kemampuan para siswa soal cerita di berikan juga bertujuan agar siswa lebih menggemari matematika, karena soal cerita berkaitan dengan kehidupan atau kenyataan seharihari di lingkungan (Rosyidi, 2005).

Menurut Rahardjo dan Waluyati (2011:8), soal cerita dan soal non cerita dapat digunakan untuk mengukur kemampuan siswa dalam pembelajaran matematika.

Berdasarkan keterangan diatas, dapat dikatakan soal cerita berkaitan dengan kehidupan sehari-hari dan penyelesaiannya dapat dilakukankan dengan mengubah menjadi model matematika. Soal cerita juga berfungsi melatih proses berpikir deduktif dan analitis serta melatih kemampuan berhitung siswa.

\section{Sistem Persamaan Linear Dua Variable (SPLDV)}

Bentuk umum Persamaan Linear Dua Variable (PLDV): $a x+b y+c=0$, dengan $a, b \neq 0$ dan $a, b, c \in$ $R$, dimana $x$ dan $y$ disebut variabel (peubah) dan $a, b$ disebut koefesien dan $c$ disebut konstanta.

Sistem Persamaan Linear Dua Variabel (SPLDV) adalah sistem persamaan dua variable yang sejenis 
berpangkat satu dan apabila digambarkan dalam bidang cartesius akan membentuk kumpulan garis lurus.

Bentuk umum SPLDV:

$$
\begin{gathered}
a_{1} x+b_{1} y=c_{1} \\
a_{2} x+b_{2} y=c_{2} \\
\vdots \\
a_{n} x+b_{n} y=c_{n}
\end{gathered}
$$

Dengan $x$ dan $y$ disebut variabel, $a_{1}, a_{2}, \ldots, a_{n}, b_{1}, b_{2}, \ldots, b_{n}$ disebut koefesien, dan $c_{1} c_{2} \ldots c_{n}$ disebut konstanta dan , $a_{1}, a_{2}, \ldots, a_{n,}, b_{1}, b_{2}, \ldots, b_{n}, c_{1}, c_{2}, \ldots, c_{n} \in \mathbb{R}$.

Pokok pembahasan soal cerita materi SPLDV yang diberikan di sekolah antara lain:

1) Cara mengetahui soal cerita yang diberikan merupakan sistem persamaan linear dua variabel.

2) Strategi penyelesaian model matematika yang diperoleh menggunakan metode SPLDV.

Kemampuan siswa dalam melakukan penyelesaian matematika dari masalah yang berkaitan dengan SPLDV merupakan kemampuan dasar yang digunakan sebagai tujuan dasar pembelajaran untuk mengembangkan kemampuan aplikasi matematika sebagai solusi permasalahan kehidupan sehari-hari. Untuk meningkatkan solusi perlu juga dikembangkan kemampuan mengetahui masalah meliputi: memastikan yang diketahui dalam soal dan memastikan yang ditanyakan dalam soal, menyusun model matematika, menyelesaikan masalah dan menafsirkan solusinya.

\section{Metode AnAlisis Kesalahan NeWMan}

Metode analisis kesalahan Newman seringkali digunakan untuk menganalisis siswa yang kesulitan memahami soal cerita matematika. Dengan memperbanyak latihan soal dan praktik, siswa diharapkan dapat memperbaiki kesalahan dalam menyelesaiakan soal cerita. Dengan mengetahui faktor-faktor kesalahan siswa tersebut, guru dapat menetukan sikap dan strategi pengajaran untuk mengatasi kesulitan yang dialami siswa tersebut (White, 2010).

Kesalahan siswa yang dikaji dalam penelitian ini adalah kesalahan yang ditinjau berdasarkan fase Newman yang didasarkan atas hasil pemeriksaan jawaban siswa dalam menyelesaikan soal cerita materi SPLDV.

Menurut Newman dalam Singh (2010) siswa harus melewati 5 fase berurutan dijelaskan sebagai berikut:

1. Kesalahan membaca (reading eror)

Kesalahan membaca ialah kondisi siswa tidak mengetahui kata kunci dalam soal sehingga tidak mendapati penyelesaian dari soal tersebut. Kemampuan membaca soal cerita berpengaruh terhadap sikap siswa tersebut untuk menyelesaikan sebuah permasalahan.

\section{Kesalahan Memahami Masalah (Comprehension} Error)

Kesalahan memahami masalah ialah kondisi siswa dapat membaca soal dengan baik, tetapi tidak dapat menyatakan ketentuan dalam soal sehingga siswa tidak berhasil menyelesaikan permasalahan tersebut.
3. Kesalahan Transformasi (Transformation Error)

Kesalahan transformasi ialah kondisi siswa dapat memahami masalah dan menyatakan ketentuan dalam soal namun tidak berhasil mengubah ke bentuk persamaan yang cocok untuk menyelesaikan permasalahan.

4. Kesalahan Keterampilan Proses (Process Skills Error)

Kesalahan ketrampilan proses ialah kondisi siswa dapat menggunakan operasi matematika yang cocok, tetapi masih keliru dalam menggunakan langkahlangkah perhitungan. Kesalahan ini merupakan kesalahan siswa dalam proses berhitung.

5. Kesalahan mengembalikan jawaban model ke masalah awal (Encoding Error)

Kesalahan mengembalikan jawaban model ke masalah awal ialah kondisi siswa telah merampungkan perhitungan dengan benar hingga akhir, namun tidak mampu menyusun hasil akhir yang dimaksud soal dengan tepat sehingga menyebabkan maksud jawaban berubah.

Menurut keterangan diatas dapat disimpulkan dalam menyelesaikan soal cerita banyak kemungkinan letak kesalahan yang bisa dilakukan oleh siswa. Demikian peneliti akan melakukan observasi terhadap hasil kerja siswa dalam menemukan penyelesaian soal cerita materi SPLDV dengan metode analisis kesalahan Newmann.

\section{JENIS KESALAHAN DAN LETAK KESALAHAN}

Kesalahan ketika menyelesaikan soal matematika umumnya terjadi pada saat proses pencarian solusi soal hingga hasil akhirnya. Kesalahan yang terjadi berkaitan dengan kesalahan dalam memahami soal, kesalahan dalam menerapkan prosedur ataupun dalam membuat kesimpulan diakhir.

Menurut Rosyidi (2005) kesalahan siswa dapat di tinjau dari jenis dan letak kesalahan. Kesalahan siswa tersebut dijelaskan sebagai berikut:

1. Jenis kesalahan adalah kesalahan dalam menyelesaikan soal yang berkaitan dengan konsep, prinsip, dan operasi.

2. Letak kesalahan adalah ketidaksesuaian atau penyimpangan jawaban siswa dengan yang benar.

Jenis kesalahan dalam pencarian solusi soal cerita SPLDV di tinjau dari objek kajian matematika. Menurut wijaya (2011) untuk menentukan jenis kesalahan yang dilakukan siswa dapat menggunakan indikator-indikator sebagai berikut:

1. Kesalahan konsep

Adapun indikator siswa yang melakukan kesalahan konsep adalah:

a. Keliru memahami soal yaitu keliru dalam menuliskan apa yang diketahui dan apa yang di tanyakan.

b. Keliru tentang konsep peubah, yaitu keliru dalam membuat permisalan.

c. Keliru dalam membuat model matematika dari soal 
d. Keliru tentang konsep eliminasi dan subtitusi.

2. Kesalahan prinsip

Adapun indikator siswa melakukan kesalahan prinsip adalah:

a. Keliru dalam menerapkan aturan-aturan metode eliminasi dan subtitusi.

b. Keliru dalam menentukan hasil akhir soal dan penarikan kesimpulan.

c. Keliru menentukan satuan dari objek yang diminta dalam soal.

3. Kesalahan operasi

Adapun indikator siswa melakukan kesalahan operasi adalah:

a. Keliru menentukan hasil operasi yang sesuai, baik operasi penjumlahan, pengurangan, perkalian maupun pembagian.

b. Siswa menentukan jawaban tidak melalui prosedur langkah-langkah suatu operasi.

Letak Kesalahan dan indikator kesalahan berdasarkan fase Newman yang dapat dikembangakan menurut Clemen 1980 dalam Oktaviana (2017:26) sebagai berikut:

Tabel 1 Indikator Letak Kesalahan Siswa

\begin{tabular}{|c|c|c|}
\hline No. & Letak Kesalahan & Indikator \\
\hline 1. & $\begin{array}{l}\text { Kesalahan } \\
\text { membaca } \\
\text { (Reading error) }\end{array}$ & $\begin{array}{l}\text { a. Siswa keliru membaca } \\
\text { kata-kata, symbol, } \\
\text { istilah, atau informasi } \\
\text { penting dalam soal. }\end{array}$ \\
\hline 2. & $\begin{array}{l}\text { Kesalahan } \\
\text { memahami } \\
\text { (Comprehension } \\
\text { error) }\end{array}$ & $\begin{array}{l}\text { a. Siswa tidak memahami } \\
\text { yang ditanyakan dalam } \\
\text { soal. } \\
\text { b. Kesalahan menangkap } \\
\text { informasi pada soal } \\
\text { sehingga tidak mampu } \\
\text { menyelanjutkan ke } \\
\text { proses selanjutnya. }\end{array}$ \\
\hline 3. & $\begin{array}{l}\text { Kesalahan } \\
\text { transformasi } \\
\text { proses } \\
\text { (Transformation } \\
\text { error) }\end{array}$ & $\begin{array}{l}\text { a. Siswa tidak berhasil } \\
\text { mengubah informasi } \\
\text { dalam soal cerita ke } \\
\text { bentuk model } \\
\text { matematika yang tepat. } \\
\text { b. Siswa keliru dalam } \\
\text { menggunakan simbol } \\
\text { operasi hitung untuk } \\
\text { menyelesaikan soal. }\end{array}$ \\
\hline 4. & $\begin{array}{l}\text { Kesalahan } \\
\text { keterampilan } \\
\text { Proses (Process } \\
\text { Skill error) }\end{array}$ & $\begin{array}{llr}\text { a. } & \begin{array}{l}\text { Siswa keliru saat } \\
\text { menghitung atau } \\
\text { melakukan proses }\end{array} \\
\text { komputasi. } \\
\text { b. } \begin{array}{l}\text { Siswa tidak mampu } \\
\text { menyelesaikan proses } \\
\text { perhitungan }\end{array} \\
\end{array}$ \\
\hline 5. & $\begin{array}{l}\text { Kesalahan } \\
\text { mengembalikan } \\
\text { jawaban model }\end{array}$ & $\begin{array}{llr}\text { a. Siswa tidak mampu } \\
\text { menuliskan jawaban } \\
\text { akhir yang sesuai }\end{array}$ \\
\hline
\end{tabular}

\begin{tabular}{|l|l|l|}
\hline $\begin{array}{l}\text { ke masalah awal } \\
\text { (Encoding } \\
\text { error) }\end{array}$ & b. & $\begin{array}{l}\text { dengan apa yang } \\
\text { diminta dalam soal } \\
\text { Siswa tidak mampu } \\
\text { menyimpulkan dengan } \\
\text { tepat hasil akhir dari } \\
\text { mdoel matematika } \\
\end{array}$ \\
& c. $\begin{array}{l}\text { yang telah dibuat. } \\
\text { Kesalahan karena } \\
\text { ketidaktelitian siswa }\end{array}$ \\
\hline
\end{tabular}

Faktor-faktor yang Mempengaruhi Kesalahan Siswa

Dalam kegiatan belajar mengajar siswa banyak melakukan kegiatan antara lain mengamati, menyerap informasi yang didapat dalam kegiatan pembelajaran dlam kelas. Dalam kegiatan pembelajaran, adakalanya berjalan kurang lancar, masing-masing siswa memiliki kekecakapan yang tidak sama dalam menyerap informasi yang didapat dari guru. Selama proses belajar mengajar banyak pertanyaan yang diajukan oleh siswa kepada guru, salah satu faktor pertanyaan itu muncul karena siswa mengalami kesulitan dalam menyerap informasi yang diberikan. Kesulitan yang dihadapi oleh siswa menjadi salah satu faktor siswa melakukan kesalahan dalam penyelesaian solusi soal.

Secara umum faktor yang berpengaruh pada kesalahan dapat dipisahkan menjadi dua, yaitu faktor intern dan faktor ekstern, penjelasan Susilo dalam Malik (2017:4)

Adapun faktor kesalahan menurut Newman dalam White (2015) berdasarkan kognitif dan non kognitif yaitu:

1. Faktor penyebab kesalahan membaca
a. Kurang mengerti makna kalimat yang diminta

b. Terburu-buru dalam mengerjakan soal

2. Faktor penyebab kesalahan memahami
a. Kurang mengerti permasalahan soal
b. Kurang cermat
c. Terbiasa mengerjakan soal cerita tanpa menuliskan yang diketahui dan yang ditanyakan
d. Terburu-buru menyelesaikan soal

3. Faktor penyebab kesalahan transformasi
a. Kurang mengerti permasalahan soal
b. Kurang cermat
c. Tidak menuliskan metode yang digunakan
d. Terburu-buru menyelesaikan soal

4. Faktor penyebab kesalahan keterampilan proses
a. Tidak mengerti masalah
b. Kurangnya pembiasaan diri dalam mengerjakan soal cerita yang variasi
c. Kurangnya kemampuan menangkap informasi soal
d. Keliru menangkap informasi dari guru
e. Kurang cermat
f. Kurang mengerti sepenuhnya materi prasyarat

5. Faktor penyebab kesalahan dalam penulisan jawaban
a. Kurang cermat
b. Terburu-buru dalam mengerjakan soal 
Berdasarkan penjelasn diatas dapat dikatakan bahwa kesalahan-kesalahan yang dilakukan oleh siswa dapat mempengaruhi hasil kerjanya. Kesalahan-kesalahan yang dilakukan siswa itu bisa juga berasal dari faktor siswa itu sendiri termasuk faktor kognitif maupun non-kognitif. Dalam penelitian ini faktor penyebab yang dimaksud dilihat dari faktor kognitif karena waktu yang dibutuhkan relatif singkat. Faktor kognitif ialah kemampuan intelektual siswa dalam menyelesaikan soal cerita materi SPLDV menggunakan fase Newman. Faktor-faktor penyebab kesalahan siswa dalam setiap fase menyangkut faktor kognitif akan ditelusuri sedetail mungkin melalui interview.

\section{METODE PENELITIAN}

Dalam penelitian ini, sumber data yang digunakan adalah siswa kelas VIII. Subjek yang digunakan sebanyak dua siswa yakni, satu siswa laki-laki kelas VIII SMP Tembilahan Hulu dan satu siswa perempuan kelas VIII SMP 22 Pekanbaru. Subjek peneitian 1 dikodekan SL (Siswa Laki-Laki) dan subjek penelitian kedua dikodekan SP (Siswa Perempuan). Kedua subjek merupakan siswa melakukan kesalahan terbanyak, memeliki variasi letak, jenis dan penyebab kesalahan paling banyak serta komunikatif. Kami memberikan tes tidak hanya untuk dua siswa tersebut, jika iya ceritakan sedikit.

Peneliti berlaku sebagai instrumen utama, soal cerita, dan pedoman interview. Soal tes dan interview merupakan metode pengumpulan data yang digunakan dalam penelitian ini. Selanjutnya, semua hasil tes dan interview dianalisis menggunakan tiga tahapan, yaitu reduksi, penyajian, dan penarikan kesimpulan.

Soal cerita yang diberikan yaitu soal yang dipakai untuk menganalisis kesalahan siswa dalam menyelesaikan soal cerita materi SPLDV jika pada model matematikanya koefisiennya bertanda sama.

\section{Soal:}

Suatu hari Eko disuruh ibunya untuk membeli $2 \mathrm{~kg}$ buah apel dan $4 \mathrm{~kg}$ buah salak di pasar. Ketika di jalan ia bertemu dengan neneknya. Dan neneknya juga menyuruh Eko membeli $4 \mathrm{~kg}$ buah apel dan $2 \mathrm{~kg}$ buah salak di pasar. Sesampai pasar Eko membeli buah sesuai pesanan. Sesudah mendapatkan buahnya Eko segera pulang. Sesampainya dirumah Eko ditanya berapa harga $1 \mathrm{~kg}$ masing-masing buah. Eko bingung karena si penjual hanya memberi tahu harga $2 \mathrm{~kg}$ apel dan 4 kg salak sebesar Rp 36.000,00 dan untuk pesanan neneknya $4 \mathrm{~kg}$ dan $2 \mathrm{~kg}$ salah sebesar Rp 30.000,00. Bantu Eko yuk teman-teman untuk mencari berapa harga 1 kg masing-masing buahnya!

\section{TEKNIK ANALISIS DATA Analisis Data Kualitatif}

Hasil jawaban kedua subjek akan dianalisis kemudian disesuaikan dengan hasil interview, untuk menelusuri letak dan jenis kesalahan serta penyebab ternjadinya kesalahan siswa.

Analisis ini dilakukan secara berurutan mulai dari SL dan SP.

\section{HASIL DAN PEMBAHASAN}

HASIL

Berdasarkan hasil tes tulis yang dilakukan, diperoleh hasil berupa bentuk-bentuk kesalahan yang dilakukan subjek penelitian.

\subsection{Subjek SL}

Berikut disajikan hasil pengerjaan SL pada gambar 1.

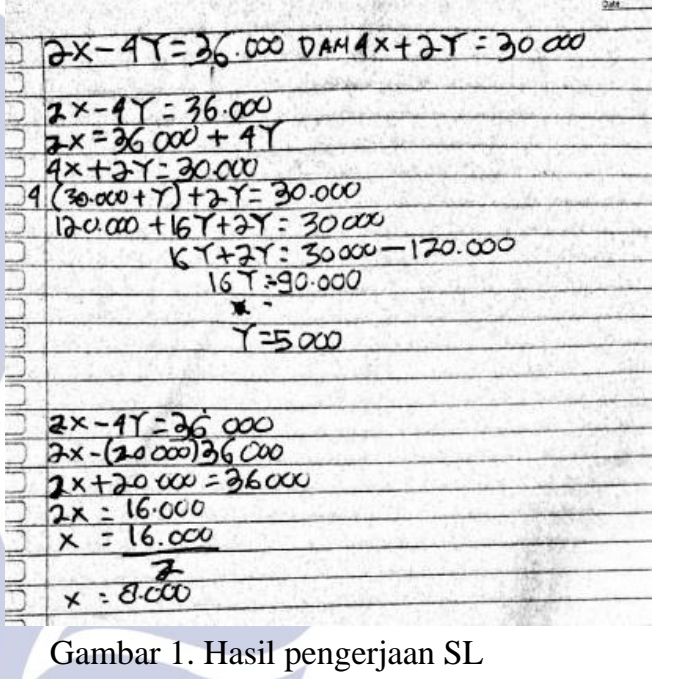

Table 2. Transkrip Interview SL

\begin{tabular}{|c|c|}
\hline Kode & Kegiatan \\
\hline $\mathrm{P}-1$ & Coba baca soalnya. \\
\hline SL-1 & "membaca" \\
\hline P-2 & $\begin{array}{l}\text { Sudah paham apa saja yang } \\
\text { diketahui dalam soal? }\end{array}$ \\
\hline SL-2 & $\begin{array}{l}\text { Dalam soal yang diketahui yaitu } \\
\text { Eko membeli } 2 \mathrm{~kg} \text { apel dan } 4 \mathrm{~kg} \\
\text { salak seharga } 36.000 \text { lalu } 4 \mathrm{~kg} \text { apel } \\
2 \mathrm{~kg} \text { salak } 30.000\end{array}$ \\
\hline $\mathrm{P}-3$ & Lalu apa yang ditanya dalam soal ? \\
\hline SL-3 & $\begin{array}{l}\text { Yang ditanya adalah berapa harga } 1 \\
\text { kg masing-masing buah }\end{array}$ \\
\hline $\mathrm{P}-4$ & $\begin{array}{l}\text { Apakah kamu masih bingung } \\
\text { menentukan variablenya? }\end{array}$ \\
\hline SL-4 & Lumayan \\
\hline $\mathrm{P}-5$ & $\begin{array}{l}\text { Variable } x \text { dan } y \text { melambangkan } \\
\text { apa? }\end{array}$ \\
\hline SL-5 & 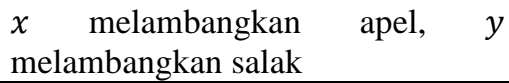 \\
\hline P-6 & $\begin{array}{ll}\text { Kenapa kamu } & \text { menuliskan } 2 x- \\
4 y=36.000 & \text { dan } 4 x+2 y= \\
30.000 ? & \end{array}$ \\
\hline SL-6 & Tidak tahu \\
\hline
\end{tabular}




\begin{tabular}{|c|c|}
\hline P-7 & $\begin{array}{llll}\text { Disini apa yang mau } & \text { kamu } \\
\text { subtitusikan? }\end{array}$ \\
\hline SL-7 & $x$ nya \\
\hline P-8 & $\begin{array}{l}\text { Coba amati apakah yang kamu } \\
\text { subtitusikan sudah benar? }\end{array}$ \\
\hline SL-8 & Oh iya, salah, kurang teliti \\
\hline P-9 & Apa yang salah? \\
\hline P-9 & $\begin{array}{ll}\text { Harusnya } & 4(36.000+4 y)+ \\
2 y=30.000 & \end{array}$ \\
\hline $\mathrm{P}-10$ & Apa kamu yakin? \\
\hline SL-10 & Sepertinya begitu \\
\hline $\mathrm{P}-11$ & $\begin{array}{l}\text { Ini bukannya } 2 x=36.000+4 y ? \\
\text { kenapa kamu subtitusikan ke } x \text { ? }\end{array}$ \\
\hline SL-11 & Oh iya salah, kurang teliti \\
\hline $\mathrm{P}-12$ & $\begin{array}{lll}y=5000 & \text { kamu } & \text { dapatkan } \\
\text { darimana? } & & \\
\end{array}$ \\
\hline SL-12 & $\begin{array}{l}\text { Dari } \frac{90.000}{16} . \text { Oh iya salah harusnya } \\
\frac{90.000}{18}\end{array}$ \\
\hline $\mathrm{P}-13$ & $\begin{array}{l}\text { Kenapa tidak ditulis } \\
\text { akhirnya? }\end{array}$ \\
\hline SL-13 & $\begin{array}{l}\text { Ini jawabannya, } x=8.000 y= \\
5.000\end{array}$ \\
\hline P-14 & $\begin{array}{l}\text { Kenapa tidak ditulis dalam bentuk } \\
\text { narasi sesuai yang ditanyakan } \\
\text { dalam soal. Misal pakai jadi... }\end{array}$ \\
\hline SL-14 & $\begin{array}{l}\text { Biasanya begini saja tidak papa bu, } \\
\text { yang penting ketemu jawabannya. }\end{array}$ \\
\hline
\end{tabular}

Dari hasil pengerjaan SL, peneliti mendapati SL tidak benar dalam menjawab soal.

Dari hasil jawaban, SL salah pada fase transformasi yaitu memodelkan informasi dalam soal cerita menjadi bentuk persamaan linier tetapi tidak tepat. Hal ini dimungkinkan SL tidak memahami konsep variabel atau SL tidak mampu dalam menerjemahkan soal cerita ke dalam bentuk kalimat matematika.

SL salah menjawab di fase keterampilan proses yaitu salah dalam proses perhitungan. Hal ini dimungkinkan SL tidak memahami konsep subtitusi dengan baik.

SL salah menjawab pada fase menuliskan jawaban akhir atau mengembalikan jawaban model ke masalah awal.

Dari hasil interview SL memahami maksud soal ialah berusaha menemukan harga $1 \mathrm{~kg}$ apel dan harga $1 \mathrm{~kg}$ salak. Namun, dalam membuat model matematika SL mengalami kesulitan menentukan model yang tepat sesuai dengan soal cerita. Selanjutnya dalam mengolah model yang telah dibuat, SL ceroboh dalam menghitung persamaan pertama $(2 x=36000-4 y)$ yang disederhanakan secara tepat untuk dilakuan subtitusi pada persamaan kedua $(4 x+2 y=$ 30000) sehingga SL juga salah dalam menentukan jawaban akhir. Kesalahan pada fase ini karena SL tidak menuliskan ulang bentuk lain persamaan pertama (seharusnya: $x=18000+$ $2 y$ ). SL memahami konsep subtitusi namun salah dalam konsep variabel. SL juga mengaku sering lupa dalam menulis kesimpulan sesuai yang dimaksud dalam soal karena tidak terbiasa menuliskan kesimpulan pada akhir pengerjaan soal cerita.

\subsection{Subjek SP}

Berikut hasil pekerjaan yang dilakukan SP dapat dilihat pada gambar 2 .

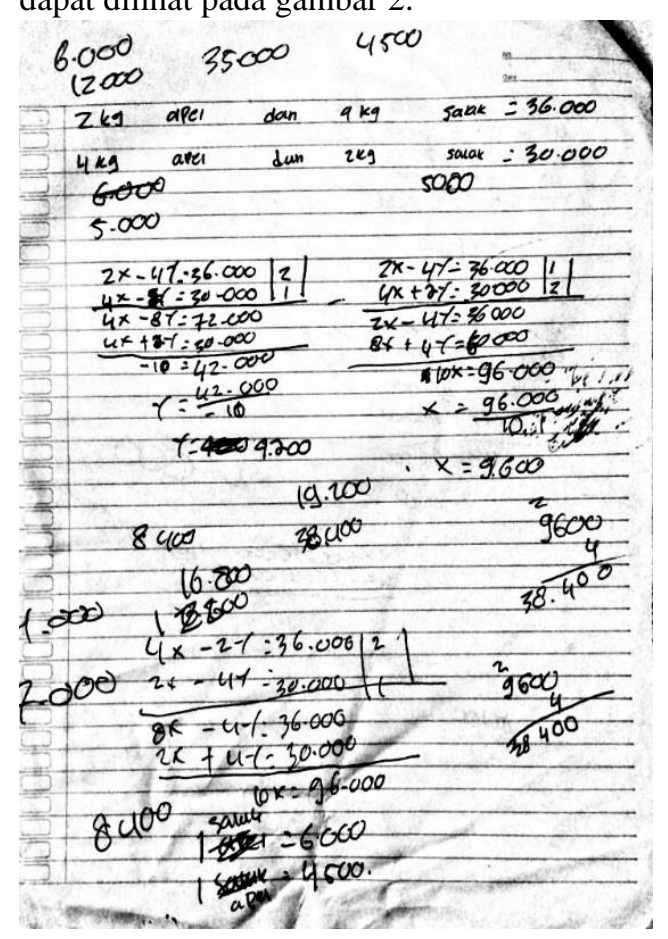

Gambar 2. Hasil pengerjaan SP

Table 3. Transkrip Interview SP

\begin{tabular}{|l|l|}
\hline Kode & \multicolumn{1}{|c|}{ Kegiatan } \\
\hline P-1 & Coba baca soalnya. \\
\hline SP-1 & *membaca* \\
\hline P-2 & Sudah memahami soalnya? \\
\hline SP-2 & Lumayan \\
\hline P-3 & $\begin{array}{l}\text { Kalau belum memahami apa yang } \\
\text { kamu lakukan? }\end{array}$ \\
\hline SP-3 & Membacanya ulang, sampai paham \\
\hline P-3 & $\begin{array}{l}\text { Nah sekarang, apa yang kamu } \\
\text { ketahui dari soal? }\end{array}$ \\
\hline SP-3 & $\begin{array}{l}\text { Eko membeli 2 kg apel dan } 4 \text { kg } \\
\text { salak seharga 36.000 dan 4 kg apel } \\
\text { dan 2 kg salak seharga 30.000 }\end{array}$ \\
\hline P-4 & $\begin{array}{l}\text { Kenapa kamu menuliskan } 2 x-4 y \\
\text { dan 4x }-2 y ?\end{array}$ \\
\hline SP-4 & $\begin{array}{l}\text { Karena sama-sama membeli apel } \\
\text { dan salak. } x \text { melambangkan apel dan } \\
y \text { melambangkan salak }\end{array}$ \\
\hline
\end{tabular}




\begin{tabular}{|c|c|}
\hline P-5 & $\begin{array}{l}\text { Lalu metode apa yang kamu gunakan } \\
\text { untuk mengerjakan? }\end{array}$ \\
\hline SP-5 & Eliminasi \\
\hline P-6 & $\begin{array}{l}\text { Apa yang kamu ketahui tentang } \\
\text { mengeliminasi? }\end{array}$ \\
\hline SP-6 & Mengilangkan dengan mengurangi \\
\hline P-7 & Itu saja? \\
\hline SP-7 & $\begin{array}{l}\text { Jadi untuk menghilangkan variabel } \\
\text { harus dikurangi dengan variabel } \\
\text { yang sama }\end{array}$ \\
\hline P-8 & $\begin{array}{l}\text { Lalu } y=\frac{42.000}{-10} \text { hasilnya menjadi } \\
y=4.200 . \text { kenapa tidak negative? }\end{array}$ \\
\hline SP-8 & $\begin{array}{l}\text { Karena harga tidak ada yang } \\
\text { negative }\end{array}$ \\
\hline P-9 & Lalu perhitungan di bawah ini apa? \\
\hline SP-9 & a cara subtitusi \\
\hline P-10 & $\begin{array}{l}\text { Lalu kenapa hasilnya berbeda? Mana } \\
\text { yang benar? }\end{array}$ \\
\hline SP-10 & $\begin{array}{l}\text { Tidak tahu, berarti ada yang salah } \\
\text { tadi }\end{array}$ \\
\hline $\mathrm{P}-11$ & $\begin{array}{l}1 \text { salak }=6.000 \text { dan } 1 \text { apel }=4.500 . \\
\text { Kamu dapat darimana? }\end{array}$ \\
\hline SP-11 & $\begin{array}{l}\text { Tidak tahu, karena jawaban yang } \\
\text { awal }(x=9.600 y=4.200) \text { di } \\
\text { kembalikan ke soal hasilnya salah. } \\
\text { Lalu dihitung menggunakan } \\
\text { subtitusi juga masih sama. Jadi } \\
\text { jawabannya salah }\end{array}$ \\
\hline $\mathrm{P}-12$ & ana letak kesalahannya? \\
\hline SP-12 & \\
\hline $\mathrm{P}-13$ & $\begin{array}{l}\text { Kesalahan apa saja yang kamu } \\
\text { lakukan? }\end{array}$ \\
\hline SP-13 & $\begin{array}{l}\text { Salah mengerjakan, menghitung, } \\
\text { kurang teliti }\end{array}$ \\
\hline
\end{tabular}

Berdasarkan hasil pengerjaan SP, peneliti mendapati SP tidak benar dalam menjawab soal.

Dari hasil jawaban, SP salah pada fase transformasi yaitu memodelkan informasi dalam soal cerita menjadi bentuk persamaan linier tetapi tidak tepat. Hal ini dimungkinkan SP tidak memahami konsep variabel atau SP tidak mampu dalam mengubah soal cerita ke dalam bentuk model matematika.

SP benar menjawab di fase keterampilan proses yaitu SP mampu melakukan proses perhitungan dengan benar sehingga hasil perhitungan sesuai dengan solusi model yang dibuat. Dalam hal ini peneliti mengasumsikan SP memahami konsep eliminasi dengan baik.

SP salah menjawab pada fase menuliskan jawaban akhir atau mengembalikan jawaban model ke masalah awal nampak pada bagian akhir solusi atau kesimpulan yang dikerjakan SP berbeda dengan hasil yang telah dihitung. Hal ini dimungkikan ketidaktelitian SP dalam menuliskan jawaban akhir.

Dari hasil interview SP memahami maksud soal ialah berusaha menemukan harga $1 \mathrm{~kg}$ apel dan harga $1 \mathrm{~kg}$ salak. Namun, dalam membuat model matematika SP mengalami kesalahan menentukan model yang tepat sesuai dengan soal cerita dengan tepat. Selanjutnya dalam mengolah model yang telah dibuat SP sempat tidak yakin apakah jawabnnya sudah benar, SP pun melakukan pengecekan namun tidak berhasil menemukan letak kesalahannya. Peneliti menganggap SP memahami konsep eliminasi namun salah dalam konsep variable. SP juga melakukan kecerobohan dalam menulis jawaban akhir atau kesimpulan yang sesuai dengan hasil perhitungan yang dilakukan SP $\quad($ salak $=6000$ dan apel $=$ 4500 tanpa proses perhitungan, sedangkan hasil perhitungan yang telah dilakukan $x=$ 9600 dan $y=4200$ ).

\section{PEMBAHASAN}

Berdasarkan hasil penelitian dapat dilihat siswa mengalami kesulitan pada fase memodelkan soal, memproses, dan menyimpulkan jawaban. Pernyataan tersebut sesuai dengan penelitian Susanti (2017).

Berdasarkan hasil analisis kesalahan siswa dalam menyelesaiakan soal cerita SPLDV, berikut adalah pembahasan kesalahan siswa tersebut:

1. Membaca (Reading)

Pada fase ini dikatakan siswa tidak mampu membaca atau mengenali kata kunci dalam soal sehingga siswa tidak dapat melanjutkan proses pemecahan solusi soal atau dapat dikatakan siswa tidak bisa membaca pertanyaan dan memperoleh informasi yang tersirat pada soal.

Peneliti mengasumsikan SL dan SP mengalami kesulitan dalam mengenali symbol-simbol dalam soal. Kedua subjek dapat membaca soal dengan jelas dan lantang tetapi salah dalam membaca symbol-simbol yang tersirat dalam soal sehingga model yang dibuat juga tidak tepat.

\section{Memahami (Comprehension)}

Pada fase ini dikatakan siswa mampu membaca semua kata dalam soal tetapi tidak menguasai secara keseluruhan pengertian kalimat dalam soal, sehingga siswa tidak dapat melanjutkan proses pemecahan solusi atau dapat dikatakan tidak mengetahui apa yang ditanyakan soal.

Pada fase ini ditemukan bahwa kedua subjek tidak melakukan kesalahan. Hal ini ditunjukan dengan dalam wawancara bahwa SL dan SP memahami betul apa yang 
diketahui dan apa yang ditanyakan dalam soal cerita. Keduanya juga memahami konsep subtitusi dan eliminasi dengan baik.

\section{Transformasi (Transformation)}

Pada fase ini dikatakan siswa memahami yang ditanyakan soal namun tidak bisa mengenali konsep perhitungan, seperti eliminasi atau subtitusi, dan operasi yang dibutuhkan untuk menlakukan proses pemecahan solusi dalam soal.

Pada fase ini ditemukan SL dan SP melakukan kesalahan. Hal ini ditunjukkan bahwa kedua subjek mampu mengubah informasi dalam soal cerita menjadi bentuk persamaan linier tetapi tidak tepat.

\section{Keterampilan Proses (Process skill)}

Pada fase ini dikatakan siswa telah mampu mengenali konsep perhitungan dan operasi yang tepat. Namun, tidak memahami cara yang diperlukan untuk melakukan proses komputasi dengan tepat.

Pada fase ini SL ditemukan melakukan kesalahan pada proses subtitusi karena ketidaktelitian terhadap penyederhanaan persamaan sehingga proses perhitungan tentunya tidak tepat.

SP tidak melakukan kesalahan dimana proses perhitungan menggunakan konsep eliminasi dengan baik, namun karena kesalahan yang telah terjadi pada proses sebelumnya, model yang diselesaikan dan hasil operasi matematika model pun tidak sesuai.

5. Mengembalikan Jawaban Model ke Masalah Awal (Encoding)

Pada fase ini dikatakan siswa telah menemukan solusi atas permasalahan. Namun, tidak tepat dalam menentukan jawaban akhir atau tidak menunjukkan jawaban yang benar sesuai dengan apa yang diminta dalam soal.

Pada fase ini ditemukan bahwa SL dan SP melakukan kesalahan dimana SL tidak menyimpulkan hasil dari perhitunggannya karena tidak terbiasa menuliskan kesimpulan dan SP salah dalam menyimpulkan hasil akhir dimana hasil akhir dan kesimpulannya berbeda. Dalam wawancara SP mengaku tidak teliti dalam menuliskan kesimpulan.

Berdasarkan hasil tes dan triangulasi interview, maka disimpulkan letak kesalahan, jenis kesalahan dan penyebab kesalahan yang dilakukan kedua subjek dalam pencarian solusi soal cerita materi SPLDV.

Table 4. Rangkuman Hasil Analisis Kesalahan

\begin{tabular}{|l|l|l|l|}
\hline $\begin{array}{l}\text { Kode } \\
\text { subjek }\end{array}$ & $\begin{array}{l}\text { Letak } \\
\text { kesalahan }\end{array}$ & $\begin{array}{l}\text { Jenis } \\
\text { kesalahan }\end{array}$ & $\begin{array}{l}\text { Penyebab } \\
\text { kesalahan }\end{array}$ \\
\hline
\end{tabular}

\begin{tabular}{|c|c|c|c|}
\hline SL & $\begin{array}{l}\text { K2 } \\
\text { K3 } \\
\text { K4 }\end{array}$ & $\begin{array}{l}\text { Konsep, } \\
\text { Operasi }\end{array}$ & $\begin{array}{l}\text { Lemah akan } \\
\text { konsep } \\
\text { variabel, dan } \\
\text { tidak bisa } \\
\text { menegartikan } \\
\text { soal menjadi } \\
\text { bentuk model } \\
\text { matematika. } \\
\text { Salah dalam } \\
\text { melakukan } \\
\text { operasi } \\
\text { perhitungan } \\
\text { dengan } \\
\text { benar. }\end{array}$ \\
\hline SP & $\begin{array}{l}\text { K2 } \\
\text { K3 } \\
\text { K4 }\end{array}$ & Konsep & $\begin{array}{l}\text { Lemah akan } \\
\text { konsep } \\
\text { variable dan } \\
\text { tidak bisa } \\
\text { mengartikan } \\
\text { soal menjadi } \\
\text { bentuk model } \\
\text { matematika. }\end{array}$ \\
\hline
\end{tabular}

Keterangan :

$\mathrm{K} 1$ : kesalahan memahami soal

$\mathrm{K} 2$ : kesalahan mengubah ke bentuk model persamaan

$\mathrm{K} 3$ : kesalahan menyelesaikan model persamaan

K4 : kesalahan menentukan jawaban akhir

\section{PENUTUP}

\section{Simpulan}

Berdasarkan pembahasan, kesimpulan yang diperoleh untuk letak kesalahan siswa dalam memecahkan solusi soal cerita SPLDV ada tiga yang pertama, Kesalahan dalam membuat model matematika. Kesalahan yang dilakukan siswa yaitu: keliru dalam menulis operator atau simbolsimbol dalam soal cerita dan tidak mampu menerjemahkan ke dalam soal cerita. Yang kedua, kesalahan pemecahan solusi model matematika. Kesalahan yang dilakukan siswa yaitu keliru dalam proses komputasi pemecahan solusi soal cerita. Dan yang ketiga adalah kesalahan menyimpulkan jawaban akhir soal. Kesalahan yang dilakukan siswa yaitu keliru dalam menyimpulkan jawaban akhir soal.

Jenis kesalahan siswa dalam pemacahan solusi soal cerita SPLDV ada 2 yang pertama adalah kesalahan konsep. Kesalahan yang dilakukan siswa yaitu: keliru mengubah soal menjadi bentuk model dan keliru dalam konsep variabel yang digunakan untuk mengubah ke bentuk model persamaan.yang kedua adalah kesalahan operasi. Kesalahan yang dilakukan siswa yaitu siswa tidak melakukan aturan operasi hitung dengan benar

Penyebab kesalahan yang dillakukan siswa dalam menyelesaiakan soal cerita SPLDV yang pertama adalah lemah dalam konsep variable, diantaranya tidak mampu membaca symbol-simbol yag tersirat dalam soal. Yang 
kedua adalah tidak bisa mengubah soal cerita menjadi bentuk kalimat matematika/model matematika yang tepat. Yang ketiga kurang dalam membuat persamaan ekuivalen. Dan untuk yang terakhir kurang dalam menentukan hasil perhtitungan dengan tepat.

\section{Saran}

Berdasarkan pembahasan dan kesimpulan, saran yang peneliri berikan dalam penelitian ini antara lain:

1. Guru membiasakan siswa untuk menjawab soal cerita secara lengkap dan runtut dari menuliskan apa yang diketahui, apa yang ditanya, memodelkan soal, memproses perhitungan, hingga menyimpulkan jawaban. Karena ditemui kedua siswa tidak mampu memodelkan secera tepat dan juga tidak mampu menyimpulkan jawaban model ke masalah awal.

2. Karena masih ditemui banyak kesalahan di bagian membuat model matematika maka sebaiknya guru menjelaskan dengan cara yang lebih sederhana dan mudah dipahami oleh siswa bagaimana mengubah soal cerita menjadi kalimat matematika yang baik dan benar.

\section{DAFTAR PUSTAKA}

Adriani, Parhaini. 2015. Penalaran Aljabar dalam Pembelajaran Matematika. (online), (www.jurnalbeta.ac.id diakses 19 Desember 2019)

Azis, Ilde Ilka Jade. 2016. Analisis Kesalahan Siswa SMP dalam Menyelesaikan Soal Aljabar Model TIMSS. Skripsi tidak diterbitkan. Surabaya: PPs Universitas Negeri Surabaya.

Islamiyah, Anna Citra, dk. 2018. Analisis Kesalahan Siswa SMP pada Penyelesaian Masalah Sistem Persamaan Linear Dua Variabel. (online). (www.jurnal.unsyiah.ac.id diakses 21 desember 2019

Karnasih, Ida. 2015. Analisis Kesalahan Newman Pada Soal Cerita Matematis. Paradikma jurnal pendidikan matematika. (online) (www.jurnal.unimed.ac.id diakses pada 18 januari 2020)

Malik, Abdul. 2017. Analisis Kesalahan Menyelesaikan Soal Cerita Sistem Persamaan Linear Dua Variabel (SPLDV) Pada Siswa Kelas VIII SMP Negeri 1 Orong Telu Program Pascasarjana Universitas Terbuka. Tesis diterbitkan. Surabaya : PPs Universitas Negeri Surabaya

Miles, B. M. d. M. H., 1992. Analisis Data Kualitatif Buku Sumber Tentang Metode-metode Baru. Jakarta: UIP.

Oktaviana, Dwi. 2017. Analisis jenis kesalahan Berdasarkan Teori Newman dalam Menyelesaikan Soal Cerita pada Mata Kuliah Matematika Diskrit. (Online) ( journal.lain-palangkaraya.ac.id diakses 18 januari 2020)

Parmjit singh, Arba Abdul Rahman, and Teoh Sian Hoon. 2010. The Newman Procedure for Analyzing Primary Four Pupils Errors on Written Mathematical Tasks: A Malaysian Perspective. (Online), (www.sciencedirect.com diakses pada 18 januari 2020)

Permendikbud. 2014. Kurikulum 2013 Mata Pelajaran Matematika SMP/MTs. Jakarta: Balitbang.

Rahardjo, Marsudi dan Waluyati, Astuti. 2011. Pembelajaran Soal Cerita Operasi Hitung Campuran di Sekolah Dasar (Modul Matematika SD dan SMP Program Bermutu). Yogyakarta: PPPPTK Matematika

Rahayu, Putri. 2017. Analisis Kesalahan Siswa SMP dalam Menyelesaikan Soal SPLDV. (online). (www.jurnal.ustjogja.ac.id di akses 18 januari 2020)

Rosyidi, Abdul Haris. 2005. Analisis Kesalahan Siswa Kelas II MTs Al-Khoiriyah dalam Menyelesaikan Soal Cerita yang Terkait dengan Sistem Persamaan Linear Dua Peubah. Tesis tidak diterbitkan. Surabaya: PPs Universitas Negeri Surabaya.

Susanti. 2017. Analisis Kesalahan Siswa dalam Menyelesaikan Soal Cerita Program Linear berdasarkan Tahapan Newman. Skripsi. Surabaya : Universitas Negeri Surabaya

Sunardiningsi, Ganik W., Sri Hariyani dan Trija Fayeldi. 2019. Analisis kesalahan siswa dalam menyelesaiakn soal matematika berdasarkan analisis Newman. RAINSTEK : Jurnal Terapan Sains \&Teknologi 1, no. 2:41-45

White, A. L., 2010. Numeracy, Literacy and Newman's Error Analysis. Journal of Science and Mathematics Education in Southeast Asia, 33(2), pp.129-148.

Wijaya, A.A. dan Masriyah. 2013. Analisis Kesalahan Siswa dalam Menyelesaikan Soal Cerita Sistem Persamaan Linear Dua Variabel. (Online) (www.jurnalmahasiswa.unesa.ac.id diakses 18 januari 2020) 